\title{
Historical enquiry in primary school: Teaching interpretation of archaeological artefacts from an intercultural perspective
}

\author{
Patrik Johansson* - Stockholm University, Sweden
}

\begin{abstract}
This article explores how learning historical interpretation of Viking-age archaeological artefacts from an intercultural perspective could be facilitated through historical enquiry in primary school. Three design principles were formulated for the teaching: (1) enquiry based upon an authentic intercultural question; (2) enquiry with a focus on source interpretation; and (3) enquiry using material culture in the form of archaeological artefacts. Two questions were addressed: first, how did the teaching design and practice facilitate the intended learning, and second, what obstacles to learning were encountered as a result of the design? Research data were analysed qualitatively using contentfocused conversation analysis and variation theory. The findings in relation to the first question indicated that the design principles helped teachers facilitate learning through historical enquiry from an intercultural perspective, and that archaeological artefacts can inspire investigations into history by activating pupils' historical consciousness. The answer to the second question indicated that pupils had difficulties responding to historical enquiries with synthesized inferences based on historical evidence. A revision of the final phase of the enquiry suggests that focus is on discussing reasonable explanations in relation to artefacts, rather than synthesizing historical inferences based on evidence. This study points to possibilities of teaching historical interpretation and intercultural perspectives through historical enquiry in primary school, and suggests that archaeological artefacts can be used to initiate historical learning.
\end{abstract}

Keywords: archaeological artefacts; historical enquiry; historical interpretation; intercultural learning; Swedish primary school; Viking age

\section{Introduction}

This article explores how learning the historical interpretation of archaeological artefacts from an intercultural perspective can be facilitated through historical enquiry in primary school (10-11-year-old children). The background to the research project is the growing emphasis in Western-world curricula on teaching historical enquiry (for example, Finnish National Board of Education, 2004; New Zealand Ministry of Education, 2010; Seixas and Morton, 2013, for Canada's Historical Thinking Project), while at the same time intercultural learning is gaining support because it is considered an important preparation for life in multicultural societies (Banks and McGee Banks, 2010; Byram et al., 2009; UNESCO, 2006). Another contemporary trend involves teaching critical reflection to cope with the complexities of contemporary media flows (McGrew et al., 2017; Nygren and Guath, 2018; Wineburg, 2016). Importantly, research suggests 
that critical thinking is subject specific (Nygren et al., 2019), and several scholars have argued for teaching disciplinary thinking in history (Ashby et al., 2005; Wineburg, 2016; VanSledright, 2012; Seixas and Morton, 2013). Historical enquiry is long established and widely used in Great Britain (for example, Chapman, 2017b; Cooper, 2012) and North America (for example, Levstik and Barton, 2015; Seixas and Morton, 2013; Wineburg et al., 2011) as a teaching method for organizing and structuring historical learning. It fulfils a dual purpose by developing an understanding of history as both a body of knowledge and a form of knowledge (Chapman, 2016).

Research has shown that effective teaching relies on pupils' active learning of skills involved in enquiry work. By actively investigating the past, rather than passively memorizing facts, pupils strengthen their critical thinking skills and improve their ability to handle and retain information (for example, Reisman and McGrew, 2018). Also, historical enquiry offers an alternative teaching method to the traditional textbook (Grant, 2018). Although there are proven strategies and methods for dealing with literacy issues that arise when using primary text sources (for example, Barkham, 2013; Fines, 2010; Hoodless, 2011; Nichol, 2010c, 2010b), readability issues can be a stumbling block when working with primary sources with young (especially immigrant) pupils. One method for opening up traditional narratives to new interpretations while motivating pupils is studying history through material culture, such as archaeological artefacts (Arias-Ferrer and Egea-Vivancos, 2017; Levstik et al., 2014). Often source work focuses on qualifying students' methods of historical thinking (for example, Wineburg, 2016), but in the present study the archaeological artefacts were primarily used to practise historical interpretation (compare Chapman, 2017a) and facilitate intercultural learning (Nordgren and Johansson, 2015) through historical enquiry.

When orientating young people to life in multicultural societies (Faas, 2011), history education has a role to play in the development of intercultural competences (Rathje, 2007) through intercultural learning (Nordgren and Johansson, 2015). Intercultural competences include knowledge of the historical processes of migration and cultural encounters, and the ability to decentre and interpret the representations of other cultures (Nordgren and Johansson, 2015; Nordgren, 2017). The challenge of intercultural learning lies in combining historical knowledge with the normative aspects of lifeworld experiences, to orientate individuals to life in multicultural societies. In this respect, historical learning involves historical knowledge and thinking, as well as historical orientation in the context of contemporary experience.

A problem in history education, Rüsen (2004a) argues, is that nation-based and ethnocentric narratives tend to stand in the way of intercultural learning. In Sweden, primary school history revolves much around textbook narratives, which tend to reproduce traditional accounts of events (see Grever and Van der Vlies, 2017). Nation-based narratives can be stumbling blocks to understanding history in terms of migration and cultural encounters. In the present study, historical enquiry using archaeological artefacts provided an alternative approach to intercultural perspectives on the Viking age. This approach was motivated by the prominence of the Viking narrative in Sweden (Stolare, 2017), which is still influenced by the nationalist romantic ideas of the nineteenth century (Svanberg, 2003). The Viking narrative tends to be ethnocentric, although the time period was characterized by extensive migration and cultural exchanges (Blomkvist, 2014; Cassel, 2008). In the present study, the pupils investigated why large quantities of ancient Arabic coins were found around presentday Sweden, and part of the answer was due to the far-reaching trading activities during the Viking age. 


\section{Purpose and research questions}

This article explores and describes how learning historical interpretation of archaeological artefacts from an intercultural perspective was facilitated by historical enquiry, and explores the obstacles to learning encountered as a result of the design. The different aspects of learning objectives in combination with historical and intercultural learning theory influenced the formulation of the following three design principles: (1) enquiry based upon an authentic intercultural question; (2) enquiry with a focus on source interpretation; and (3) enquiry using material culture in the form of archaeological artefacts. This article explores the relevance of the three design principles through their operationalization while teaching to facilitate the learning of historical interpretation from an intercultural perspective through historical enquiry. Two research questions are posed: first, how did the teaching design and practice facilitate the intended learning, and second, what obstacles to learning were encountered as a result of the design?

\section{Theoretical background}

Since the 1960s and 1970s, the Amherst History Project in the USA (see, for example, Brown, 1996), the Schools Council History Project 13-16 in Great Britain (for example, Shemilt, 1983) and the succeeding CHATA project (Concepts of History and Teaching Approaches: 7 to 14) (for example, Ashby, 2005), and European and American scholars such as Ashby et al. (2005), Barton (1997), Cooper (2002), Körber and Meyer-Hamme (2015), Seixas and Morton (2013), VanSledright (2012) and Wineburg (2016) have argued for teaching disciplinary historical thinking, that is, examining historical primary sources as evidence for inferences made through enquiry. Research indicates that primary school pupils are capable of learning the sophisticated historical thinking associated with enquiries when supported by appropriate teaching (Ashby et al., 2005; Barton, 1997; Cooper, 1994; Foster and Yeager, 1999; Levstik and Smith, 1996; VanSledright and Kelly, 1998), although pupils still face difficulties when dealing with multiple, and sometimes contradictory, primary sources (Afflerbach and VanSledright, 2001; Hynd, 1999; Rouet et al., 1996; Stahl et al., 1996). Researchers have shown that practising wellstructured historical enquiry has a positive impact on pupils' historical thinking overall (Cooper, 2012; Reisman, 2012a; Vella, 2010b; Wineburg and Reisman, 2015).

When choosing primary sources for enquiry, researchers have argued that material culture could be a particularly powerful way to engage understanding through enquiry, while being accessible to young pupils (Levstik et al., 2014; Nichol, 2010a; Vella, 2010a). Indeed, many teachers opt for images of artefacts, or occasionally replicas of archaeological artefacts, to minimize readability issues (Vella, 2010a; Davies and Redmond, 1998). Modern replicas may provide pupils with a tactile and physical experience of artefacts (see Horler, 2010; Pye, 2016). Images and material artefacts have proven valuable for initiating historical interpretation in young children with limited reading abilities (Dierking, 2002; Hicks and Doolittle, 2008). Research has shown that young pupils can learn to interpret images and physical artefacts in a qualified manner when they are historically contextualized and related to enquiries that pupils find engaging (Arias-Ferrer and Egea-Vivancos, 2017; Cooper, 2008; Davis, 2005; Dean, 2008; Levstik et al., 2014; Vella, 2010b). However, a recurring problem is that pupils tend to disregard historical evidence to maintain cohesion when constructing historical narratives (Barton, 1997; Foster and Yeager, 1999; Lee, 2005; Levstik and Smith, 1996; VanSledright and Kelly, 1998; VanSledright, 2002). Also, pupils tend not to acknowledge 
the need to interpret sources (Ashby, 2004) and often explain different interpretations in terms of the personal bias of witnesses or incomplete information (Afflerbach and VanSledright, 2001). However, research shows that pupils' limited understanding of historical interpretation can be rectified while teaching, if it is anticipated (Cooper, 2013; Fines and Nichol, 1997; Von Heyking, 2004; Levstik and Henderson, 2016).

The concept 'intercultural' is normative, and refers to a desired condition of mutual respect and interaction that transgresses cultural divisions (Gundara and Portera, 2008). There is an international drive to broaden regional and national histories through intercultural education, although there is limited empirical research on the implications of these perspectives in history education (Girard and McArthur Harris, 2018). This study builds on Nordgren and Johansson's (2015) definition of intercultural learning, which encompasses history as consciousness, culture and use. The concepts of narrative competence and intercultural competence are combined to create a framework where features of intercultural historical competence (Deardorff, 2009) are identified and ideas of how these can be advanced are formulated. Three essential components of intercultural learning (knowledge of social and cultural processes, the ability to interpret representations from other cultures, and the ability to decentre that is, to relativize one's own values, beliefs and behaviours) are combined with three procedures of narrative competence (the ability to experience history, to interpret history, and to orientate to history) to create a theoretical matrix with nine aspects of intercultural historical learning. The purpose of the framework is to formulate an intercultural body of knowledge, skills of interpretation and preparedness for action. Some of these were relevant for defining the learning objectives of this study (see the section on the analytical framework below).

Research confirms the persistence of Eurocentrism in courses and textbooks that may hinder intercultural perspectives (Araújo and Rodríguez Maeso, 2012; Bolgatz and Marino, 2014; Noboa, 2012; Rüsen, 2004a). Interestingly, some studies suggest that pupils may prefer world history perspectives over regional and national histories. Nygren (2011) found that pupils' global orientation did not change despite the introduction of a more Eurocentric curriculum in the 1990s, and points to Sweden's long tradition of using UNESCO standards to globalize the history curriculum, in addition to the country's small size and international dependence, to explain pupils' global orientation. Still, Eliasson and Nordgren (2016) surveyed the conditions of the intercultural aspects of history in compulsory schools in Sweden and found that the historical canon is still mainly ethnocentric and Eurocentric, although teachers perceive multiculturalism and diversity issues as important.

Studies suggest that Eurocentrism in the history classroom can be countered if it is anticipated. Bain (2006) demonstrated how pupils who learned about the medieval plague through the analysis of primary sources from different regions were able to identify a Eurocentric perspective in textbook descriptions of the Black Death. Meanwhile, in upper secondary schools, Johansson (2012) demonstrated how teaching pluralism, deconstruction and counter-narratives can broaden closed ethnocentric narratives. Disciplinary tools can develop pupils' ability to make intercultural interpretations. Previous teaching projects on Viking-age migration and cultural exchange in Europe and beyond include Dean (2010) and Nichol (2005).

\section{Analytical framework}

The main organizational and didactical framework for the project was historical enquiry, that is, the process of developing historical knowledge and understanding 
by posing questions about the past and applying skills associated with locating, analysing, evaluating and using sources as evidence to develop an informed argument or interpretation (for example, the 2012 History K-10 Syllabus (Board of Studies NSW, 2012); Cooper, 2012). Material historical culture was used as a starting point for the enquiry because it was assumed to be a powerful method for creating an engaged understanding (Arias-Ferrer and Egea-Vivancos, 2017; Levstik et al., 2014). Meanwhile, providing an approach to broaden traditional narratives to embrace intercultural perspectives includes knowledge of migration and cultural encounters (Carretero et al., 2012; Nordgren and Johansson, 2015; Rüsen, 2004a). Material culture was operationalized as archaeological artefacts, which were used as sources to reveal historical agency and the dependency between artefacts and culture (Hodder, 2012). The pupils encountered physical replicas and photographs of archaeological artefacts in the classroom, as well as original artefacts in the history museum during a final visit.

The challenge of intercultural learning lies in combining historical knowledge with the normative aspects of an intercultural perspective. In this research, the concept of historical consciousness functions as the link between these two. Historical consciousness commonly refers to human beings' natural need for temporal orientation (Rüsen, 2004b; Seixas, 2006), and the awareness that human beings, our culture and institutions exist in time such that we have a history and a future (Jeismann, 1992). In an often-used formulation, which resonates with the Swedish history curriculum, historical consciousness comprises the connection between the past, the present and the future.

Intercultural perspectives include knowledge of the past, but also experiences that enable individuals to orient themselves within multicultural societies. To better understand these connections, Rüsen's (2005) theoretical paradigm of narrative competence has been used to design an analytical framework. Rüsen's view of historical learning as attaining narrative competence first involves the experience of history, that is, perceptions of the temporal aspects of phenomena, alongside an interpretation of history, that is, connecting perceived phenomena narratively using historical tools. The third component is the ability to orient oneself historically, that is, to develop temporal perspectives to guide actions and contribute to identity formation. The main focus of this research was the first two components: the experience and interpretation of history.

Historical experience focuses on the urge to create historical meaning (Rüsen, 2005). This desire is often pre-narrative as it is initiated in a non-narrative form through an immediate experience of a discontinuity between the past and present. This experience orientates the individual to the past with implicit or explicit questions out of a desire to understand. Hence, the individual's historical consciousness is activated and the intention to historicize the past, as experienced in the present, through the process of historical interpretation is initiated. Historical interpretation, in turn, represents the transition between the pre-narrative and the narrative functions of historical learning. Interpretative work on individual artefacts can be non-narrative, and can aid the construction of historical narratives. Historical interpretation includes explanations, that is, the process of ordering and connecting facts over the course of time.

The theoretical framework for intercultural historical learning (Nordgren and Johansson, 2015) was used for design purposes, and five aspects of intercultural education were chosen as learning objectives for the teaching project (see the historical learning column in Table 1 on page 257). These aspects involved the ability to:

1. Experience one's own position in historical culture, including contemporary and historical perspectives on money and trade, and the pupils' own involvement in these activities. 
2. Experience history as cultural encounters, including continuous migration and cultural encounters during the Viking age through peaceful trading activities, as well as violent encounters.

3. Experience history from different cultural perspectives, including Scandinavian and Arabic perspectives on the Viking age, by acknowledging representatives from both cultures as rational actors.

4. Investigate sources from the past to build explanations, including the systematic exploration and interpretation of Scandinavian and Arabic, as well as hybrid, archaeological artefacts as representations of different cultures.

5. Construct meaningful historical explanations by constructing a meaningful narrative about why Arabic coins have been found around Scandinavia, while considering historical concepts, actors' motives and the causes and aspects of continuity and change.

Finally, variation theory, which defines learning as the ability to discern, was used for design purposes and as an analytical tool (Marton and Booth, 1997; Lo, 2012; Marton, 2015). Variation theory assumes that human experience consists of the simultaneous discernment of necessary aspects of a phenomenon and that this act of discernment requires variation. Variation theory has been used to design certain patterns of variation by teaching through contrasts, for example by creating contrasts between contemporary and historical artefacts, and concepts to identify variation patterns in teaching sequences.

\section{Methodology}

This research was framed as educational design research (that is, the systematic analysis of educational interventions with the aim of generating research-based solutions in practice (Plomp, 2013)). The study was conducted as a learning study, which is a theory-informed, interventionist, iterative and collaborative research approach that focuses on learning objects, how these are constituted and how they can be used to improve teaching practices (Lo, 2012; Marton, 2015). The sections below describe the circumstances of the whole learning study, but this article only deals with some of the data yielded by the research questions. Design research can result in descriptions of interventions and empirically tested design principles that provide insights into the function of the intervention (Van den Akker, 1999; Linn et al., 2004; Stoel et al., 2015). Design principles are contextually conditioned and provide no guarantee of success in other contexts, but can be validated when tested in new educational contexts.

\section{Setting}

Three schools in Stockholm, Sweden, were involved in the project: Alpha, Bravo and Charlie. School Alpha was located in a suburb of Stockholm that is considered to have a low socio-economic status, a large proportion of immigrant pupils and faces challenges promoting pupils' language skills. School Bravo was on the other end of the spectrum, in the centre of the city, and considered to have a high socio-economic status, few immigrant pupils and a high standard of language skills. School Charlie was positioned in between these two and represented a large, average city school in Sweden with a variation of pupils. The research project was conducted over a full school year (2016/17). A comparative analysis between the schools is beyond the scope of this article, but the broad spectrum represented by the schools provides an empirical width suitable to test the teaching intervention design in different contexts. 


\section{Participants}

Participating in the present research project were 56 pupils from three classes (one from each school: Alpha, $n=20$; Bravo, $n=10$; Charlie, $n=26$ ), in the fourth and fifth grades (10-11-year-old children). The pupils participating were a convenience sample as classes were selected by the teachers involved (Denscombe, 2014). The research project was designed and conducted by a group consisting of one researcher (the author) and three experienced teachers. The research group collaborated in the design, performance and evaluation of a series of enquiry-based history lessons. The teachers' roles primarily contributed to practitioners' perspectives and the design and performance of teaching, whereas the primary role of the researcher was to contribute to the relevant research, theory and analytical tools.

\section{Procedures}

Teaching was conducted as historical enquiry (Cooper, 2012; Levstik and Thornton, 2018; Reisman and McGrew, 2018), and the primary learning object was identified as the interpretation of archaeological artefacts during a historical enquiry. The second learning objective was acquiring an intercultural perspective on the Viking age. The empirical analysis examines and describes how the teaching design facilitated the learning of historical interpretation with archaeological artefacts, and the type of obstacles encountered.

Research lessons were investigated in three iterations, offset in time between the schools. The first iteration was conducted at School Bravo, the second at School Charlie and the final iteration at School Alpha. Empirical observations during the first and the second iterations resulted in some alterations to teaching methods, tasks and tools. Revisions involved small adjustments, including elaborations of the enquiry questions, and textual revisions of the interpretation model and worksheets, as well as tweaked teacher instructions.

\section{Data collection}

Research data were collected during the lessons and consisted of transcriptions of audio recordings of classroom and group discussions, as well as pupils' notes on worksheets. Transcriptions of teachers' and pupils' conversations in classes and groups comprised the primary data and the worksheets from the group work were used to supplement the conversation analysis. First, data related to the four steps of the enquiry sequence were identified, and second, data relevant to the research questions were selected for further analysis.

\section{Data analysis}

Data were analysed qualitatively, and those episodes connected to the steps in the enquiry sequence (see Table 1) were analysed using a combination of content-focused conversation analysis and variation theory (Emanuelsson and Sahlström, 2008; Marton, 2015). Learning comprised changed co-participation in historical enquiry practice (Rogoff, 2003) and the discernment of learning objects (Marton, 2015). The contentfocused approach resembled traditional conversation analysis (Norrby, 2004) but instead of focusing on the conversational structure, the focus was on the subject content constructed through social interaction (Sahlström, 2008; Melander and Sahlström, 2009). Thus, analytical interest was directed to the object that the pupils were focused upon in a specific situation, in this case a historical enquiry using archaeological 
artefacts. According to variation theory, what is possible to learn (that is, discern) is constituted by patterns of simultaneous variation, for example contrasting patterns in interactions between teachers and students, and between students without teachers being present (Marton, 2015).

The research process involved multiple close readings of the transcripts to identify patterns in the conversations that indicated the facilitation of discernment and appropriate participation in the enquiry. Dialogues in the empirical section have been selected to illustrate representative patterns in the pupils' conversations. The qualitative analysis strived for heuristic validity (that is, the ambition is to formulate interpretative patterns and configurations, which can be recognized in the empirical world (Larsson, 2005 , 2009). The present study strived to enhance the degree of generalizability by including a diverse range of schools and pupils from different socio-economic contexts, with varying language skills and cultural backgrounds (Larsson, 2009).

\section{Design}

The enquiry design built on established classroom practices, such as reading activities, group work, whole-class discussion and worksheets, in order to establish a predictable and repeatable sequence (see Reisman, 2012a; Stodolsky, 1998; Stoel et al., 2015). Hence, the enquiry was not an open-ended endeavour for the pupils, although interpretations and inferences were expected to differ. The teachers led classes as interpreters of sources who were required to perform an expert reading without falling back on the familiar habit of narrating history (see Barton, 1997). The need for proper modelling and explicit instruction has been pointed out by several researchers (Duke and Pearson, 2002; Harris and Graham, 1996; Nokes and Dole, 2004; Stoel et al., 2015), as reading strategies remain invisible unless they are brought to the surface and named (Collins et al., 1989; Collins et al., 1991).

Three design principles were formulated for the enquiry, based on historical and intercultural learning theory, empirical findings from educational research and the professional experience of the research group (see Van den Akker, 2013; Plomp, 2013; Johansson and Thorsten, 2017). The design principles guided the design of the intervention and associated teaching activities, tasks and tools. The design principles can be described as: (1) enquiry based upon an authentic intercultural question; (2) enquiry with a focus on source interpretation; and (3) enquiry using material culture in the form of archaeological artefacts.

The first design principle encouraged pupils to explore an authentic and intercultural question that was formulated as: 'Why have large quantities of Arabic coins been found around the island of Gotland?' The authentic quality of the question meant that it reflected a genuine historical problem that could inspire further investigations using primary sources (see Grant et al., 2017; Schreiber et al., 2006). The question should be complex and one that would require continuous analysis; that is, there should not be one single answer to the question that could be easily looked up in a textbook. The intercultural aspect of the question should reflect an intercultural problem of historical and contemporary relevance that would demand an intercultural answer. The hypothesis was that an authentic question could engage pupils' metacognitive reflections (see Lee, 2005; Ashby et al., 2005) and invite pupils to explore a historical mystery that the teachers could not answer conclusively.

The second design principle focused on source interpretation. An easy to use interpretation model based on questions was created to facilitate learning historical interpretation (see Figure 1). The model was carefully designed to generate questions that archaeologists and historians would typically use (see Cooper, 2012; Forssberg 
and Sennefelt, 2014; Hodder, 2012; Levstik et al., 2014; Wineburg, 2007). This model is referred to as the four-square model of interpretation. Each square had an overarching question: what, when, how and why, and two sub-questions that comprised two levels of enquiry (see Horler, 2010; Nuffield Primary History Project, 2010). Contextual information was provided as a brief caption in the first handout; in the second handout, additional historical information was provided that enabled further interpretation (see, for example, Blomkvist, 2014; Cassel, 2008). The first question was answered using the caption, whereas the second question required more probing and further reasoning using contextual information and the artefact. This model provided the pupils with generic questions that helped them to explore specific cultural contexts using the artefacts.

\begin{tabular}{|l|l|}
\hline What? & When? \\
What is the artefact? & When was the artefact \\
$\begin{array}{l}\text { What can the artefact tell us about } \\
\text { the time of its origination? }\end{array}$ & $\begin{array}{l}\text { manufactured? } \\
\text { Which historical period is the artefact } \\
\text { from? }\end{array}$ \\
\hline $\begin{array}{l}\text { How? } \\
\text { How was the artefact manufactured? } \\
\text { What was required for the } \\
\text { manufacture of the artefact? }\end{array}$ & $\begin{array}{l}\text { Why? } \\
\text { What was the artefact used for? }\end{array}$ \\
& $\begin{array}{l}\text { (what was someone trying to } \\
\text { achieve)? }\end{array}$ \\
\hline
\end{tabular}

Figure 1: Template providing generic questions for the interpretation of archaeological artefacts

The third design principle performed the enquiry using material culture in the form of archaeological artefacts from the Viking age. Research indicates that material culture can create an engaged understanding and promote deep thinking about past lives (Arias-Ferrer and Egea-Vivancos, 2017; Moore, 2018; Levstik et al., 2014) while revealing intercultural perspectives (Nordgren and Johansson, 2015). The pupils explored modern Swedish coins as well as physical replicas of Arabic coins to establish the enquiry question, and then used images of additional artefacts (see Appendix). Material culture was thought to be particularly powerful in the facilitation of the learning of immigrant pupils who had a limited command of the Swedish language. Historical artefacts have a certain attraction to children and encourage them to engage in further exploration of the past (Lubar and Kingery, 2013). Contact with historical artefacts can move us in time and space, open up new worlds and create and revoke memories (Pye, 2016).

The historical enquiry followed a sequence that involved four steps (see Table 1). During the first step, the enquiry question was established through an examination of the Arabic coin replicas to activate pupils' historical consciousness (Johansson, 2019). During the second step, the interpretation model was introduced, and the pupils practised interpretation using the coins and contextual facts. The intention was to establish an understanding of interpretation by asking questions and to evoke new questions. During the third step, the pupils practised historical interpretation with several archaeological artefacts. This involved the investigation of three or four artefacts and additional contextual information in groups of three or four pupils for 20 to 30 minutes per artefact. The intention was to qualify the ability to interpret artefacts. 
During the fourth step, the enquiry question was addressed through the construction of a historical explanation. Guided by the teacher, the class formulated a collective answer to the enquiry question. Pupils were asked to contribute to the answer while pointing to evidence and arguing for their interpretations and corroborating their sources.

Table 1: The four-step enquiry sequence, showing the operationalization in terms of teaching activities and intended learning outcomes

\begin{tabular}{|c|c|c|}
\hline Enquiry sequence & Teaching activities & Historical learning \\
\hline $\begin{array}{l}\text { 1. Establish enquiry } \\
\text { question through } \\
\text { archaeological } \\
\text { artefacts. }\end{array}$ & $\begin{array}{l}\text { Model the concept of trade } \\
\text { with modern coins. Explore } \\
\text { Arabic coin replicas and } \\
\text { establish enquiry question. } \\
\text { Formulate hypothesis to } \\
\text { enquiry question. }\end{array}$ & $\begin{array}{l}\text { Activate historical } \\
\text { consciousness and experience } \\
\text { enquiry question as historical } \\
\text { and meaningful. Experience } \\
\text { one's own position in historical } \\
\text { culture. }\end{array}$ \\
\hline $\begin{array}{l}\text { 2. Interpret archaeological } \\
\text { artefacts through } \\
\text { historical } \\
\text { contextualization. }\end{array}$ & $\begin{array}{l}\text { Introduce interpretation } \\
\text { model with modern coins } \\
\text { and explore coin replicas. } \\
\text { Dynamic movement between } \\
\text { artefact and contextual facts. }\end{array}$ & $\begin{array}{l}\text { Understand historical } \\
\text { interpretation and evoke } \\
\text { historical questions. Experience } \\
\text { history as cultural encounters } \\
\text { and perspectives from different } \\
\text { cultures. }\end{array}$ \\
\hline $\begin{array}{l}\text { 3. Practise historical } \\
\text { interpretation with } \\
\text { multiple archaeological } \\
\text { artefacts. }\end{array}$ & $\begin{array}{l}\text { Investigate additional } \\
\text { artefacts with interpretation } \\
\text { model and contextual facts. } \\
\text { Reformulate hypothesis. }\end{array}$ & $\begin{array}{l}\text { Practise historical interpretation } \\
\text { by asking questions. Ability } \\
\text { to investigate sources from } \\
\text { different cultures. }\end{array}$ \\
\hline $\begin{array}{l}\text { 4. Formulate answer with } \\
\text { archaeological artefacts } \\
\text { as evidence. }\end{array}$ & $\begin{array}{l}\text { Collect clues from groups. } \\
\text { Work with contrasting } \\
\text { narratives to establish } \\
\text { evidence. Formulate a } \\
\text { collective answer. }\end{array}$ & $\begin{array}{l}\text { Ability to construct meaningful } \\
\text { historical explanations } \\
\text { with artefacts as evidence. } \\
\text { Extend the historical frame of } \\
\text { reference. }\end{array}$ \\
\hline
\end{tabular}

\section{Findings}

\section{Step 1: Establish enquiry question through archaeological artefacts}

Archaeological artefacts were assumed to be a powerful method for facilitating engaged thinking while contributing to the authenticity of the question. The following excerpt shows how the teacher began by finding a handful of modern coins in her pocket to connect to pupils' prior knowledge and to model the concepts of value, goods and trade:

Teacher (T): We are going to start right here, right now. Where do these coins come from? How did they end up in my pocket? What is the coins' history?

Pupil (S)1: There are factories that make money.

S2: The money has moved around, from person to person.

T: What is this money used for?

S3: To buy things.

T: What can you buy?

S4: Candy, furniture. You can go shopping. 


\section{T: What do we shop for?}

S5: Food, vegetables, fruit, ice cream, candy, games.

T: From where do the things we buy come? For example, oranges or bananas?

S6: From warmer countries. Fruit is cultivated, and then it is shipped to the stores here.

T: So, we trade with other countries. Do we sell things as well? What could that be?

All teachers managed to establish the core concepts in a similar manner. Exploring modern coins contributed to the pupils' experience of being positioned in historical culture, as the coins originated from the 1970s until today, a time frame to which the pupils could relate. They noted that the design had changed but the king and the motto was the same, and questions were raised about what the present time period would be called in the future, if money in its physical form will remain and how coins are manufactured. The pupils formulated historical questions from examining modern coins, such as 'Did this king, Charles XVI, invent the coin?' or 'Why were coins invented?' The pupils were able to reason about these questions, stating that 'It's probably only about him being king right now', and 'It's much easier to exchange goods with money, as you can choose to trade with the person who pays more'. Some of the pupils were able to problematize the phenomenon of money in historical terms: 'Yes, it's easy to trade with money, but also more difficult as you can forge money. You cannot forge a pig. If you trade a pig for a cow, you know for sure what you get'. On the whole, most pupils were able to participate satisfactorily in the initial phase of the enquiry.

A comparison between the modern coins and their historical equivalents followed, and the pupils' historical consciousness was activated as implicit and explicit questions when material and cultural contrasts were experienced (Johansson, 2019). Material contrasts were experienced when the pupils explored the coin replicas and noted physical differences and similarities between the historical and modern coins. The modern coins were intentionally contrasted to Arabic coins, and the pupils reasoned about how the coins were made, what materials were used, how they were used and so on. Pupils were attentive to differences in appearance, materials, signs and symbols, and questions were raised over writing, materials, values and manufacturing methods. The pupils noted cultural contrasts such as differences in language, writing and cultural contexts, primarily between the Scandinavian and Arabic contexts, which could be observed in statements such as: 'Yes, I suppose it is written in Arabic, maybe the Arabs don't write like this anymore', and (to an Arabic-speaking friend) 'Can you read this?', receiving the reply 'No, but it is in Arabic and this sign means Allah'. The teacher who taught the class with a majority of immigrant pupils noted that the physical artefacts invited and included the less confident readers in the enquiry task.

Signs of an activated historical consciousness could be observed in utterances such as: 'They are really thin, but they probably didn't have machines to make them', 'Is there silver in our coins today?' and 'There are numbers on the Swedish coins, but not on these, maybe they spelled the numbers out'. These utterances could be observed as indicators of the pupils' experiences of their own position in historical culture, as they reflect a temporal awareness of the presence of the past. While exploring the Arabic replicas, the pupils began to discern motives behind the coins, such as trade, spreading the ideas of Islam, creating wealth, or using coins for jewellery. In addition, they asked questions about who could read, what the messages on the coins conveyed, 
whether they were for war or trade, what knowledge was needed to make them and what they suggested about Arabic and Swedish relations during the era.

An unforeseen contrast was activated as pupils' interest in the difference between original coins and replicas generated historical questions: 'What can we say about the past based on a replica?', 'Have they been changed in any way - are they true to the original?' and 'Are they made of the same material - is it iron or silver?'. Many pupils showed attention to detail and observed differences between the replica and the original that demonstrated that questions about authenticity remained important. During the final phase, the pupils were fortunate to be able to explore authentic Arabic coins in the history museum, making explicit the physical contrast between the replicas (which were heavy and thick steel replicas) and the originals (which were light and thin silver coins). Many pupils noted these differences and pointed them out while exploring the original coins in the museum.

\section{Obstacles}

The intercultural enquiry question was formulated by the research group prior to teaching, and the formulation influenced the pupils' thinking as they emphasized different aspects of the question. To the pupils, the question was motivated by the strange fact that Arabic coins have been found around Gotland, and this needed explanation. Several pupils focused on why the coins were buried and why they were not stored in other ways. This resulted in comments such as: 'The inhabitants of Gotland buried the silver coins like treasures' and 'They buried the coins in order to protect them'. The first statement was an example of how the information provided in the question worked to distract the pupils from the intended purpose, thus missing the intercultural aspect of the question, whereas the second statement reflected a line of thinking that corresponded with the intention of the question. Important aspects of the enquiry question included the geographical reference, the cultural affiliation of the coins and the material of the coins. Teachers should try out enquiry questions beforehand to be able to decide what elements to include or exclude, and to facilitate different understandings.

\section{Step 2: Interpret archaeological artefacts through historical contextualization}

Archaeological artefacts were specifically chosen to reveal cultural encounters and perspectives from different cultures. Besides the Arabic silver coin replicas, artefacts included photographs of an Arabic ring found in Scandinavia, a weight for a set of scales with Arabic inscriptions, a manuscript of Ibn Fadlan's story of meeting Scandinavians in Russia, a set of balance scales to weigh silver, a rune stone with a story of Scandinavian expeditions eastwards, and a Viking ship (see the Appendix for sample sources). The contrast between the geographic locality of the archaeological object (that is, where it was found and the historical/cultural context of its origin) was intended to initiate an experience of history as a cultural encounter. When the pupils discovered that the artefact was found in a location other than its origin, a growing need to explain the historical paradox could be observed in the pupils' discussions and the questions that they raised. Connecting the artefacts to contextual historical information facilitated pupils' ability to think historically and to ask more specific questions. This dynamic can be observed in this extract:

S1: The question is whether the silver came via Stockholm, if the Vikings had fetched it, or if the people from Baghdad transported it here? 
S2: It might have something to do with the rune stone.

S3: But wasn't it the Swedes who went there?

S1: But why have they found so many Arabic silver coins?

S2: Because the people from Gotland went back and forth.

S1: But it could be that the people from Baghdad came here. They could have travelled over the Russian rivers as well.

The dynamic between the artefact and contextual facts generated historical thinking. The pupils' experiences could not be explained by what they knew, so they formulated new narratives to correspond with what was being observed. Here they needed an intercultural narrative of trade and cultural encounters for the artefacts to make sense. As these pieces of the puzzle were not in place, pre-narratives were partly formulated in terms of questions. Hence, the artefacts engaged the pupils' historical consciousness, and contextual information furthered their ability to interpret the artefacts. Generating a dynamic between the particular and the general - single artefacts and historical contexts - created a situation where historical questions could be formulated. The archaeological artefacts contributed to providing meaning to historical concepts such as Vikings or thralls, epoch names such as Iron Age or Bronze Age, geographical references such as Birka or Baghdad, temporal references such as $B C$ or $A D$, and general but unfamiliar concepts, such as amber, pelts or trade.

The dynamics between artefacts and contextual information propelled the pupils forward as the questions created a need for more historical facts. The contextual information in turn deepened the pupils' understanding of the artefact, thus enhancing the pupils' ability to ask more precise questions. This dynamic can be observed in the following extract where the pupils explore the Arabic ring and read from a text:

S1: [Reading] 'The ring was made of silver and contains an encased piece of coloured glass.'

S2: So, it wasn't a gemstone?

S3: But it's almost the same; it's just that they are different materials.

S1: [Reading] 'It probably says for, or to, Allah. The ring has probably gone directly from the manufacturer and ended up in the woman's grave.'

S2: Was it to God, it said?

S1: Yes, or if God, if God wants. Or for, or to, Allah. I suppose that means that Scandinavians worked, and that Arabs had direct contact. The Scandinavians had direct contact with the Arabs.

The pupils began to discern Scandinavian and Arabic cultural perspectives during their conversation. Hence, this type of artefact, along with the contextual information, revealed the discernment of an intercultural perspective. The artefacts that contained a narrative (for example, the Scandinavian rune stone and the Arabic manuscript) were particularly effective in conveying intercultural perspectives. For instance, from lbn Fadlan's manuscript the pupils reasoned:

It was probably more likely that the Arabs came to us. Because it was so nice there. They were cleverer, so they probably came to Sweden, rather than us going to them. They could go by boat this way. 
During a later episode, having explored the rune stone, the same pupils reasoned:

Ok, so the Vikings went there. We don't think that only the Arabs came to Sweden. The Arabs wanted to trade. We don't just think that the Arabs wanted to trade with the Swedish, but also that the Swedish wanted to trade with the Arabs. We think they traded.

Ibn Fadlan's story indicated the Arabs' interest in the northern hemisphere, and the rune stone pointed to the Scandinavians' interest in the Arabic sphere. Thus, this dynamic between the artefacts encouraged intercultural interpretations and facilitated the discernment of different cultural perspectives.

\section{Obstacles}

In cases where a traditional textbook with a single narrative is used (which is common in many Swedish classrooms), there is always the risk that the text is perceived as providing the correct answer. Much work was put into writing and testing the contextualizing texts, which turned out to be a difficult balancing act between saying enough to facilitate interpretation, but not so much that a single answer was provided and the desire to explore was neutralized. During the first iteration, only a brief caption was provided with the artefact, which hampered a reasonable level of participation, so during the second iteration, more historical information was provided (see the Appendix). The pupils occasionally expressed frustration about not being provided with one definitive answer. This was expected, and can be seen as part of learning how to reason historically through enquiry. During the process of working through the artefacts, most pupils accepted enquiry work as something of a puzzle to be solved.

Pupils closed down interpretations when historical phenomena were named in a way to carry everyday meanings. This occurred in some cases in relation to epochs, artefacts and nations. For instance, epoch names could create problems when the name of the period and the material of an artefact did not correspond. Pupils had problems associating silver coins with the Iron Age ('Should there be a silver age?') or a set of bronze scales with the Iron Age. However, it should be noted that names of historical phenomena also introduce possibilities, and can provide a starting point for teaching (for example, why an Arabic ring from AD 800-900 was referred to as the 'Allah ring' in the media).

\section{Step 3: Practise historical interpretation with multiple archaeological artefacts}

The order of the archaeological artefacts introduced was important, as new items facilitated the discernment of additional aspects of an intercultural perspective. Returning to the example of the rune stone and the Arabic manuscript, the pupils' perceptions of historical events changed as new artefacts were provided. After exploring Ibn Fadlan's manuscript, the pupils thought that it was more likely that the Arabs came to Scandinavia, emphasizing a unidirectional migration. However, when they explored the rune stone, which indicated that Scandinavians sailed eastwards along the Russian rivers, the pupils' perceptions changed to include a more dynamic view of cultural encounters. Hence, the use of archaeological artefacts had some power to dislodge perceptions. This progression could be observed in other sequences of artefacts. Another example was a group who initially explored a set of balance scales that were manufactured and used around Scandinavia during the Viking age and then explored a weight for the scales with Arabic-like scribblings on it. The writing was not 
readable but was supposed to imitate Arabic writing. However, one sign on the weight was authentic, communicating that the weight was of good quality (Arabic 'bakh'). The scales connected to the trade narrative, and the weight emphasized cultural exchange and hybridization, thus emphasizing intercultural dynamics. The pupils' thinking could be observed in comments such as: 'In Sweden they wanted to do things like in Arabia', 'This is the Arabic find. In Sweden they tried to mimic and make a correct weight to make it blend in' and 'These are not Arabic signs. These were made in Sweden. In Sweden they had copied the signs and tried to make them the same way'.

The pupils' conversations show that the investigation of several artefacts improved their ability to make more precise observations and formulate better questions. This was probably connected to the pupils' growing contextual knowledge due to their engagement with the artefacts. As their contextual knowledge grew, their ability to interpret new artefacts and make more complex intercultural inferences increased. These changes in perceptions could be traced through the pupils' revisions of their hypotheses. In some cases, the initial hypothesis was left unaltered, but most added facts and inferences to their hypothesis. In a few cases, the hypothesis was discarded altogether. An initial hypothesis could be formulated like this: 'I think the Arabs were on their way to grab jewellery and money in Gotland, and the Vikings hid them in different places. One evidence is the boats'. After having studied more artefacts, including the rune stone and the ring, the pupil changed the hypothesis and added the following: 'Scandinavians traded with the Arabs, they went by boat to the Arabic countries, there they traded to get the ring from the Arabs'. New artefacts influenced revisions of hypotheses used to conduct the enquiry, and most hypotheses reflected an improved ability to recognize intercultural narratives.

Interestingly, the investigation of archaeological artefacts was particularly effective at facilitating the discernment of historical agency by revealing how individuals and groups became actors in history. Probing questions associated with how and why (see Figure 1) made the pupils attentive to historical actors' knowledge and motives. In discussions of how the artefacts were made and what was required to make them, pupils identified possible motives and the rationale behind historical phenomena. The following extract exemplifies how the pupils explored the Arabic silver coins and started to discern possible motives:

S1: What was the artefact used for? To negotiate, to buy. What should we write?

S2: To buy, to trade, to buy stuff.

S3: Why? Let's do this one quickly. To trade with each other or to negotiate.

S2: Why was it made?

S1: For wealth.

S2: Yes, to become wealthy.

\section{Obstacles}

The sequence in which the artefacts were introduced expanded pupils' interpretations, but not all combinations were equally effective. Several combinations of artefacts were tried, but all groups started with the Arabic coins and then investigated another two or three artefacts. Sequences where artefacts were not connected in a logical manner caused problems. For instance, one group started exploring the engraved weight instead of the set of scales. Without knowing how a set of balance scales worked, 
the pupils were confused about the weight and the function it had in weighing. For instance, the pupils mistakenly interpreted the weight as a model to stamp coins.

The pupils' endurance was an issue due to the demands of staying focused and exploring several artefacts in detail. These pupils were limited to working with three or four artefacts per enquiry. For some pupils it was difficult to understand the relationship between different types of questions, especially the relationship between the overarching enquiry question and the probing questions provided by the interpretative model.

\section{Step 4: Formulate answer with archaeological artefacts as evidence}

The original intention was to facilitate pupils' ability to provide historical answers to the enquiry question independently in groups. During enquiry work, most pupils were able to formulate and revise condensed hypotheses, and also to refer to some of the artefacts as evidence by connecting one artefact at a time to the enquiry question. However, all three teachers found that the final process of synthesizing observations and conclusions into one coherent and complex explanation was too difficult. Hence, the decision was made to direct interactions through whole-class discussions during the final phase. The teachers were careful to maintain the epistemic stance of historical enquiry by continuously reminding the pupils to refer to the evidence they had for their reflections, but also to highlight problems with interpretations by helping them to identify important inferences:

T: This thing about trade, have you found any evidence that they traded with the Arabs? Money is one form of evidence of course. Have you found anything else?

S1: The set of bronze scales.

T: Exactly, to be able to weigh the value of the silver.

S2: The travel report. It was that text.

T: It was an Arab traveller and narrator who told what happened.

S3: Thorsten was going to send it, but then he died.

T: He might have encountered some Vikings, maybe not Thorsten's ship specifically, but some of those who went before or after, and it's not entirely impossible that it was Thorsten's ship. This text tells us that Arabs travelled north.

The whole-class discussion followed a typical question-answer discourse, and all groups were able to contribute with observations derived from their investigations. Although the pupils could not formulate a definitive answer to the enquiry question independently, the final step engaged the pupils in considerable historical discussions. The teacher chose to formulate one collective narrative in real time based on the pupils' responses by projecting the computer screen so that all pupils could follow and influence the writing process. Consequently, the class ended up with a single written narrative. The pupils were invited to revise their hypotheses as a final step, and naturally these revisions largely resembled the collective narrative. To assess learning, a posttest was devised that asked pupils to construct a historical explanation to a similar, but new historical enquiry formulated as: 'How come Chinese silk has been found in a Viking grave in Birka?' The pupils used some archaeological artefacts from the enquiry, and a few new artefacts were added in connection to a visit to the history museum. 
Most pupils could formulate an explanation that connected the archaeological artefacts to the phenomenon of trade. The teachers assessed that between 70 and 80 per cent of the pupils managed to formulate an answer that conformed to curriculum expectations, which included references to trading activities connected to the artefacts. This indicated an increase in the pupils' ability to construct meaningful explanations due to this teaching method. One advanced pupil responded like this during the post-test:

I think people from China went by boat/hiked some distance and sold silk. Then Arabs bought silk and then the silk came to Sweden through trade with other countries. They might have travelled like this [arrows pointing to map]. They probably did this to earn money, because silk was fairly expensive. The reason why people bought silk, I think, was because it was smooth and because they thought it was beautiful. I think this because we have learned that they hiked/went by boat to other countries. Historical evidence: boats and rune stones have been found where you can see this.

One important learning outcome was that very few pupils lapsed into fictitious narratives during the post-test. Fictitious associations in history were observed prior to the practice of enquiry. There were still limitations to many of the pupils' explanations, however. For instance, many pupils tended to ascribe historical events and phenomena to specific individuals, and some had an insufficient understanding of the concept of trade. Some pupils did not fully understand that trade is a structural and continuous historical phenomenon, rather than just a transaction between two individuals.

\section{Obstacles}

During the final step, the pupils were addressed as experts on their archaeological artefacts, but they did not individually synthesize inferences with artefacts as evidence. The construction of one collective narrative may have countered the pupils' willingness to formulate independent explanations and played to their instinct for identifying a 'correct' answer. It was necessary for the teachers to model the final step of making inferences, and it is difficult to judge to what degree the class-collaborative approach enabled the intended learning. The question was raised, was it possible for the pupils to work more independently on the final task using other types of scaffolding?

Throughout enquiry work, the teachers were reminded that it was difficult for the pupils to synthesize observations independently. Although the pupils worked systematically with each artefact, when revising their hypotheses and constructing explanations some tended to disregard what had been observed during enquiry work. Some groups occasionally relapsed to eventification and fictitious thinking, and made up stories that made the pieces fit together. Although the pupils could investigate individual artefacts competently during enquiry work, it was obviously difficult for them to construct coherent explanations based on the evidence.

\section{Summary and discussion}

This article addresses two research questions: first, how did the teaching design and practice facilitate the intended learning, and second, what obstacles to learning were encountered as a result of the design? The findings yielded by the first question indicated that archaeological artefacts can be a powerful inspiration to investigate history by activating young pupils' historical consciousness (see Levstik et al., 2014; Johansson, 2019; Nichol, 2010a; Vella, 2010a). Also, historical enquiry can support 
learning about applying intercultural perspectives (Nordgren and Johansson, 2015). Clearly, pupils in the fourth and fifth grade (10-11-year-old children) can engage in disciplinary enquiry, and archaeological artefacts can support the learning process (see Cooper, 2012; Vella, 2010b). The focus should be on the initial phases of enquiry, by engaging with historical problems, asking questions and contextualizing observations, rather than on the final phases of constructing historical explanations supported by evidence. These findings comply with previous research investigating the potential role of material culture in recognizing historical agency and intercultural perspectives (Arias-Ferrer and Egea-Vivancos, 2017; Levstik et al., 2014). It supports the findings of scholars such as Cooper (2012) and Reisman (2012a, 2012b) who advocated the potential of enquiry-based teaching to facilitate historical learning, both in terms of content knowledge and disciplinary thinking, an issue that sometimes causes tension.

The three design principles (enquiry based upon an authentic intercultural question, enquiry with a focus on source interpretation, and enquiry using material culture in the form of archaeological artefacts) helped organize teaching that facilitated the learning of historical enquiry from an intercultural perspective. The first step in the enquiry sequence was established through engagement with material culture, which activated pupils' historical consciousness through contrasting modern Swedish and historical Arabic coins, which introduced an intercultural perspective (see Johansson, 2019). The choice of artefact was significant, as the coins managed to reflect contemporary and historical phenomena. Also, historical authenticity played a role in the design (see Dean, 2008). The second step involved connecting the artefacts to contextual information that facilitated pupils' ability to think historically by posing historical questions and interpreting the artefacts (see Huijgen et al., 2018). Artefacts that contained narratives were particularly effective at conveying perspectives from different cultures.

The third step enhanced the experience of history as an intercultural encounter by exploring different cultural perspectives via several artefacts. The process of investigating multiple artefacts improved pupils' abilities to make more precise observations and formulate higher-quality questions. This was probably connected to the pupils' growing contextual knowledge. A specific sequence of artefacts can reveal intercultural perspectives by facilitating the discernment of historical agency. However, the order of the artefacts introduced should be tested beforehand. The first three steps built on each other naturally and offered a reasonable progression in learning. However, there was a gap in progression to the fourth step, which involved a class collaboration rather than constructing individual answers. The teachers assessed that whole-class discussions following a question-answer discourse was the most appropriate method for formulating a single collective narrative response to the enquiry with the help of the class. Consequently, the pupils generated a single narrative through their enquiry. Regardless, the post-test showed that there was an increase in the pupils' ability to construct meaningful historical explanations from the artefacts.

The second research question identified difficulties previously described by other researchers, who had observed that pupils tend to disregard historical evidence when responding to historical enquiries (for example, Barton, 1997; Byrom, 1998; Levstik and Barton, 2015). Another difficulty was connected to the pupils' tendency to quickly embrace narratives provided by the history textbook, rather than trying to construct their own explanations (Levstik and Barton, 2015). The challenge was to provide just enough contextual information. If the pupils got too little information, they were left guessing and at risk of generating ahistorical explanations, but if they got too much information, they lost interest in the enquiry. 
These findings suggest that the final step should be revised to better align with the age group. Pupils of this age could engage in discussions of historical explanations based on investigations of the artefacts, without being required to make explicit connections between inferences and evidence. Young pupils could benefit from focusing more on the questions than on the answers during historical enquiry as a way of establishing the concept of evidence and the idea of history as being interpretative (see Levstik and Barton, 2015). A reasonable reformulation for the final step could be 'to discuss historical explanations based on archaeological artefacts'. Hence, the focus would emphasize discussing reasonable explanations in relation to the enquiry and the artefacts, rather than on the abstract process of synthesizing inferences. This method would engage and support the pupils in constructing historical narratives more critically and independently, rather than fuelling the pupils' instincts to identify the correct answer in the textbook (see Cooper, 2002; Levstik and Barton, 2015). Rather, they could learn to use the textbook to contextualize the artefacts.

Teaching historical interpretation through historical enquiry using material culture can open traditionally closed narratives for intercultural interpretation. Historical enquiry can make a valuable contribution to teaching history, and is a reasonable approach to teaching history in primary school too. In Sweden, the enquiry approach could help to counterbalance the traditional focus on textbook narratives of history and establish an appropriate epistemic practice. Engaging primary school pupils in historical enquiry work by connecting archaeological artefacts to enquiry questions could facilitate the intercultural experience of cultural encounters and perspectives from different cultures. For primary school children, an appropriate approach would engage the children by asking questions to aid the interpretation of artefacts in relation to contextual facts, rather than focusing on synthesized inferences based on historical evidence, that is, providing an answer.

\section{Acknowledgements}

This work was done in collaboration with the project A Common Space, supported by the Swedish National Heritage Board (RÄ̈), grant number 3.2.2-5180-2016. I gratefully acknowledge the three teachers who enthusiastically participated in the research project, and Kenneth Nordgren for comments on the manuscript.

\section{Notes on the contributor}

Patrik Johansson is a doctoral student in the Department of Humanities and Social Sciences Education, Stockholm University. His research interests involve historical enquiry and work with primary sources in history, in primary and secondary schools. He is currently involved in the Common Space Project (2017-20), exploring ways in which heritage can be incorporated in history education and used to address processes of migration and cultural encounters.

\section{Appendix}

Sample sources with captions and additional contextualizing facts (translated from Swedish). Sources with caption and contextualizing facts were printed on separate cards and handed out in stages. Archaeological artefacts were specifically chosen to highlight intercultural aspects such as migration and cultural encounters. 


\section{Source 1: Arabic coins

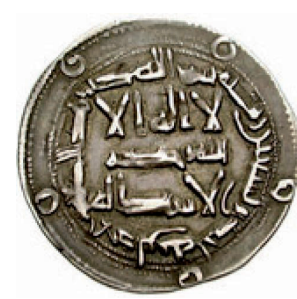 \\ (Photograph: Wikimedia Commons) \\ Arabic silver coins from Damascus and Baghdad found in Uppland. More than 85,000 Arabic coins from AD 700-800 have been found around present-day Sweden. Most have been found in locations such as Gotland, Oland and around Lake Malaren. Contacts between Scandinavia and the Arabic regions were apparently lively (Source: The Swedish History Museum).}

\section{Fact card: Arabic coins}

Arabic coins were used in the Middle East, around the Caspian Sea and the Black Sea. The coins were also used for business purposes around the Baltic Sea. The coins were then weighed, as it was the weight of the silver that decided the value. Probably, few Scandinavians could read the writings on the coins, but most refer to Islam and the Koran. Many of the coins were minted in Baghdad, which was the capital of the caliphate. Most coins have been found in Gotland, so the island must have played a key role in the far-reaching trade. During this period, it was unsafe to travel across the Mediterranean, so some trade took the route along the Russian rivers instead. Archaeologists believe that Scandinavians traded with iron, amber, furs, wool and weapons, but most importantly, with slaves (thralls). So, why were the coins buried in the ground? It is likely that the silver had to be hidden safely when enemies threatened. If the owner died or disappeared, no one knew where the coins had been hidden, so they were forgotten about. Some researchers think that some coins were buried for religious purposes, as a sacrifice to the gods.
Source 2: Balance scales

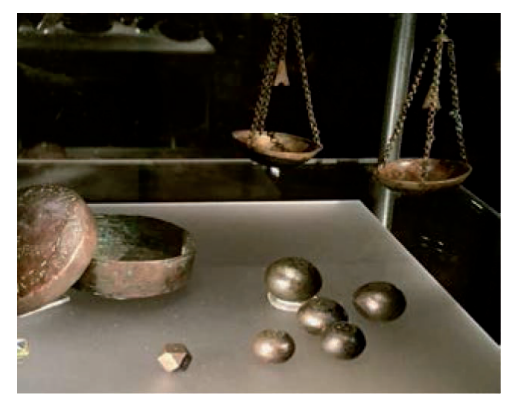

(Photograph: Patrik Johansson)

A set of balance scales of bronze (copper and tin) with weights and box used by a Scandinavian trader some time between AD 800 and 900. The scales were kept in the box (left) and were easy to carry. On the right are the weights. The scales were found close to Stockholm (Source: The Swedish History Museum).

\section{Fact card: Balance scales}

A trader's scales have been found close to Stockholm. In order to decide the value of the silver, Scandinavian traders used a set of balance scales that were easy to carry. The balance scales were necessary as they engaged in barter. In Scandinavia, goods were traded for other goods, but in the Arabic regions goods were bought and sold with silver coins. For Scandinavians, it was the metal of the silver that was valuable, so the balance scales were used to weigh the silver. Therefore, the scales and weights were an essential part of the trader's gear along with the trading goods, of course. The scales were not used to weigh the goods, but to weigh the payment - the silver. If the payment did not equal the full denomination of a coin, coins were divided into smaller parts with a knife or by bending the coins. Sometimes a piece of a bracelet was cut off. 


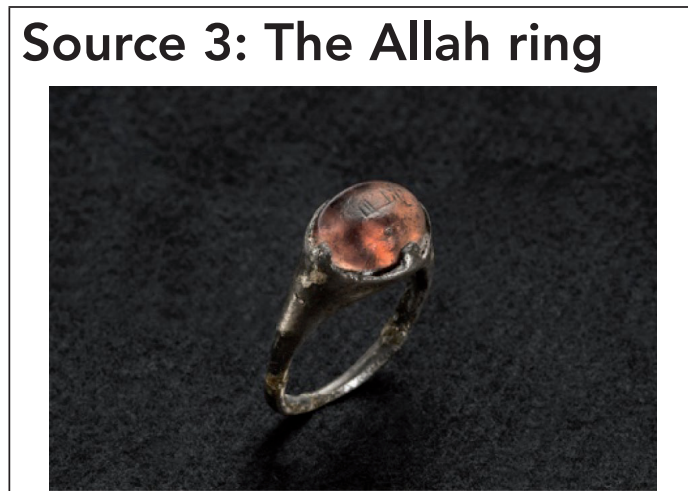

(Photograph: Wikimedia Commons)

Viking-age ring with 'Allah' engraved in Arabic. The ring has been called the 'Allah ring' and was found in a woman's grave in the trading town of Birka near Lake Malaren. The woman died some time in the 800s. The ring shows few signs of wear, so it has not been used much (Source: The Swedish History Museum).

\section{Fact card: The Allah ring}

The ring was made from silver with a piece of glass mounted on top with an inscription in Arabic. It probably says 'for' or 'to Allah', or possibly 'if God wants', but the archaeologists are not certain, as the writing is hard to read. The ring is from the Viking age and was found in a woman's grave on the island of Bjorko close to the trading town of Birka. The woman was buried in the 800s. The ring still has file marks that have not been worn off. The ring has probably left the manufacturer and then quite soon ended up in the woman's grave. The ring indicates that Scandinavians and Arabs were in direct contact with each other. Archaeologists think that someone brought the ring home to the woman, or that the woman visited Bjorko, where she died and was buried in Scandinavian attire. The ring was not used as a finger ring but was hung from a clamping buckle - a metal buckle that held up the Viking-age dungaree skirt. It is difficult to say where the ring was manufactured, but the archaeologists think that it was made around the Caspian Sea. The ring is the only Viking-age ring found in Scandinavia that can be connected to Islam.

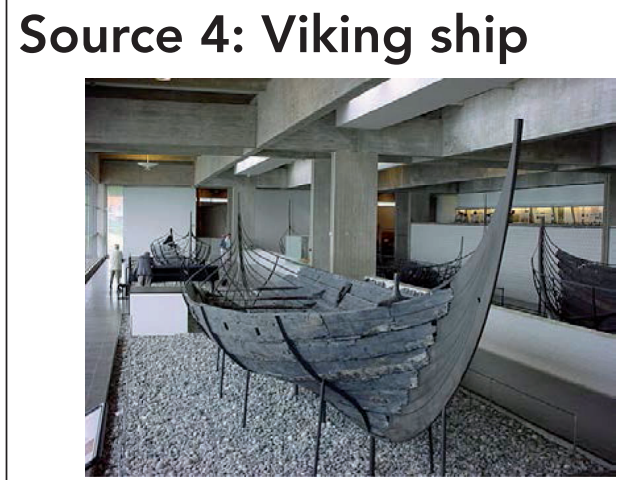

(Photograph: Wikimedia Commons)

The ship was found in Denmark and was built around the year AD 1000. It was a rather small ship with a crew of between five and eight. It was 14 metres long and could be sailed or rowed with oars on the rivers (Source: The Viking Ship Museum in Roskilde).

\section{Fact card: Viking ship}

Scandinavians were skilled boatbuilders and sailors. They could cross open seas by sail, or take the river routes through countries. The ships were built in different sizes and for different purposes. Some were built to be fast and shallow, and could approach a coastline, for an attack for instance, while other ships could carry heavy cargo across open seas. Some boats were smaller and light enough to be drawn across land between the rivers in Russia. The ships were long and narrow and could be both rowed and sailed. The mast could be tilted if they had to cross under a bridge or row up-wind. The boat in the photo could carry cargo and a crew of eight. The cargo contributed to the stability of the boat, and although it was fully loaded the draught was only about one metre, so they could go almost anywhere. Sometimes, the ships were adorned with a dragon's head in the bow to frighten enemies. Viking ships were clinker-built. This means that the boards that form the sides of the boat overlap and are kept together with rivets through the hull. Typically, the ships were pointed fore and aft. 


\section{References}

Afflerbach, P. and VanSledright, B. (2001) 'Hath! Doth! What? Middle graders reading innovative history text'. Journal of Adolescent and Adult Literacy, 44 (8), 696-707.

Araújo, M. and Rodríguez Maeso, S. (2012) 'History textbooks, racism and the critique of Eurocentrism: Beyond rectification or compensation'. Ethnic and Racial Studies, 35 (7), 1266-86.

Arias-Ferrer, L. and Egea-Vivancos, A. (2017) 'Thinking like an archaeologist: Raising awareness of cultural heritage through the use of archaeology and artefacts in education'. Public Archaeology, 16 (2), 90-109.

Ashby, R. (2004) 'Developing a concept of historical evidence: Students' ideas about testing singular factual claims'. International Journal of Historical Learning, Teaching and Research, 4 (2), 44-55.

Ashby, R. (2005) 'Students' approaches to validating historical claims'. In Ashby, R., Gordon, P. and Lee, P. (eds) Understanding History: Recent research in history education (International Review of History Education 4). London: RoutledgeFalmer, 20-33.

Ashby, R., Lee, P.J. and Shemilt, D. (2005) 'Putting principles into practice: Teaching and planning'. In Donovan, M.S. and Bransford, J.D. (eds) How Students Learn: History, mathematics, and science in the classroom. Washington, DC: National Academies Press, 79-178.

Bain, R.B. (2006) 'Rounding up unusual suspects: Facing the authority hidden in the history classroom'. Teachers College Record, 108 (10), 2080-114.

Banks, J.A. and McGee Banks, C.A. (eds) (2010) Multicultural Education: Issues and perspectives. 7th ed. Hoboken, NJ: Wiley.

Barkham, J. (2013) 'Local history and literacy using written (and other) sources'. Primary History: The Primary Education Journal of the Historical Association, 64, 28-9.

Barton, K.C. (1997) '“I just kinda know": Elementary students' ideas about historical evidence'. Theory and Research in Social Education, 25 (4), 407-30.

Blomkvist, N. (2014) 'De två haven som blev ett'. In Sjöberg, M. (ed.) En samtidig världshistoria. Lund: Studentlitteratur, 460-85.

Board of Studies NSW (2012) History K-10 Syllabus. Sydney: Board of Studies NSW.

Bolgatz, J. and Marino, M. (2014) 'Incorporating more of the world into world history textbooks: A review of high school world history texts'. World History Connected, 11 (2). Online. https:// tinyurl.com/gns9arc (accessed 13 July 2019).

Brown, R.H. (1996) 'Learning how to learn: The Amherst Project and history education in the schools'. The Social Studies, 87 (6), 267-73.

Byram, M., Barrett, M., Ipgrave, J., Jackson, R. and Méndez García, M. (2009) Autobiography of Intercultural Encounters: Context, concepts and theories. Strasbourg: Council of Europe.

Byrom, J. (1998) 'Working with sources: Scepticism or cynicism? Putting the story back together again'. Teaching History, 91, 32-5.

Carretero, M., Asensio, M. and Rodríguez-Moneo, M. (eds) (2012) History Education and the Construction of National Identities. Charlotte, NC: Information Age Publishing.

Cassel, K. (2008) Det gemensamma rummet: Migrationer, myter och möten. Huddinge: Södertörns högskola.

Chapman, A. (2016) 'Developing historical and metahistorical thinking in history classrooms: Some reflections on research and practice'. Humanities and Social Studies Education Online, $5(2), 1-17$.

Chapman, A. (2017a) 'Historical interpretations'. In Davies, I. (ed.) Debates in History Teaching. 2nd ed. London: Routledge, 100-12.

Chapman, A. (2017b) 'Research and practice in history education in England: A perspective from London'. Journal of Social Studies Education, 6, 13-43.

Collins, A., Brown, J.S. and Holum, A. (1991) 'Cognitive apprenticeship: Making thinking visible'. American Educator, 15 (3), 6-46.

Collins, A., Brown, J.S. and Newman, S. (1989) 'Cognitive apprenticeship: Teaching the craft of reading, writing, and mathematics'. In Resnick, L.B. (ed.) Knowing, Learning, and Instruction: Essays in honor of Robert Glaser. Hillsdale, NJ: Lawrence Erlbaum Associates, 453-94.

Cooper, H. (1994) 'Children's Learning, Key Stage 2: Recent findings'. In John, P. and Lucas, P. (eds) Partnership and Progress: New developments in history teacher education and history teaching. Sheffield: The Division of Education, University of Sheffield, 48-61.

Cooper, H. (2002) History in the Early Years. 2nd ed. London: RoutledgeFalmer.

Cooper, H. (2008) 'What are the reasons for linking art and history?'. Primary History: The Primary Education Journal of the Historical Association, 49, 32-4.

Cooper, H. (2012) History 5-11: A guide for teachers. 2nd ed. London: Routledge. 
Cooper, H. (2013) 'Supporting creative learning in history'. In Cooper, H. (ed.) Teaching History Creatively. London: Routledge, 19-25.

Davies, J. and Redmond, J. (1998) Coordinating History across the Primary School. London: Falmer Press.

Davis, M.E. (2005) How Students Understand the Past: From theory to practice. Walnut Creek, CA: AltaMira Press.

Dean, J. (2008) 'The power of the visual image in learning: The Nuffield Primary History approach'. Primary History: The Primary Education Journal of the Historical Association, 49, 22-3.

Dean, J. (2010) 'Viking traders: Lesson plan (KS2)'. Historical Association, Primary history resources. Online. www.history.org.uk/primary/resource/3742/viking-traders (accessed 4 August 2019).

Deardorff, D.K. (2009) 'Synthesizing conceptualizations of intercultural competence: A summary and emerging themes'. In Deardorff, D.K. (ed.) The Sage Handbook of Intercultural Competence. Los Angeles: Sage, 264-70.

Denscombe, M. (2014) The Good Research Guide: For small-scale social research projects. 5th ed. Maidenhead: Open University Press.

Dierking, L.D. (2002) 'The role of context in children's learning from objects and experiences'. In Paris, S.G. (ed.) Perspectives on Object-Centered Learning in Museums. Mahwah, NJ: Lawrence Erlbaum Associates, 3-16.

Duke, N.K. and Pearson, P.D. (2002) 'Effective practices for developing reading comprehension'. In Farstrup, A.E. and Samuels, S.J. (eds) What Research Has to Say about Reading Instruction. 3rd ed. Newark, DE: International Reading Association, 205-42.

Eliasson, P. and Nordgren, K. (2016) 'Vilka är förutsättningarna i svensk grundskola för en interkulturell historieundervisning?'. Nordidactica: Journal of Humanities and Social Science Education, 2, 47-68.

Emanuelsson, J. and Sahlström, F. (2008) 'The price of participation: Teacher control versus student participation in classroom interaction'. Scandinavian Journal of Educational Research, 52 (2), 205-23.

Faas, D. (2011) 'The nation, Europe, and migration: A comparison of geography, history, and citizenship education curricula in Greece, Germany, and England'. Journal of Curriculum Studies, 43 (4), 471-92.

Fines, J. (2010) 'Reading the past: Written and printed sources'. Primary History: The Primary Education Journal of the Historical Association, 56, 5-7.

Fines, J. and Nichol, J. (1997) Teaching Primary History. Oxford: Heinemann.

Finnish National Board of Education (2004) National Core Curriculum for Upper Secondary Schools 2003 (Regulation 33/011/2003). Helsinki: Finnish National Board of Education.

Forssberg, A.M. and Sennefelt, K. (eds) (2014) Fråga föremålen: Handbok till historiska studier av materiell kultur. Lund: Studentlitteratur.

Foster, S.J. and Yeager, E.A. (1999) '"You've got to put together the pieces": English 12-yearolds encounter and learn from historical evidence'. Journal of Curriculum and Supervision, 14 (4), 286-317.

Girard, B. and McArthur Harris, L. (2018) 'Global and world history education'. In Metzger, S.A. and McArthur Harris, L. (eds) The Wiley International Handbook of History Teaching and Learning. Hoboken, NJ: Wiley-Blackwell, 253-80.

Grant, S.G. (2018) 'Teaching practices in history education'. In Metzger, S.A. and McArthur Harris, L. (eds) The Wiley International Handbook of History Teaching and Learning. Hoboken, NJ: WileyBlackwell, 419-48.

Grant, S.G., Swan, K. and Lee, J. (2017) Inquiry-Based Practice in Social Studies Education: Understanding the inquiry design model. New York: Routledge.

Grever, M. and Van der Vlies, T. (2017) 'Why national narratives are perpetuated: A literature review on new insights from history textbook research'. London Review of Education, 15 (2), 286-301.

Gundara, J.S. and Portera, A. (2008) 'Theoretical reflections on intercultural education'. Intercultural Education, 19 (6), 463-8.

Harris, K.R. and Graham, S. (1996) Making the Writing Process Work: Strategies for composition and self-regulation. Cambridge, MA: Brookline Books.

Hicks, D. and Doolittle, P.E. (2008) 'Fostering analysis in historical inquiry through multimedia embedded scaffolding'. Theory and Research in Social Education, 36 (3), 206-32.

Hodder, I. (2012) Entangled: An archaeology of the relationships between humans and things. Chichester: Wiley-Blackwell.

Hoodless, P. (2011) 'Planning links with literacy'. Primary History: The Primary Education Journal of the Historical Association, 57, 32. 
Horler, H. (2010) 'Artefact handling at Brunel's SS Great Britain... Touch, look, listen, smell - but please don't taste!'. Primary History: The Primary Education Journal of the Historical Association, 54, 27-30.

Huijgen, T., Holthuis, P., Van Boxtel, C., Van de Grift, W. and Suhre, C. (2018) 'Students' historical contextualization and the Cold War'. British Journal of Educational Studies, 1-30. Online. https:// tinyurl.com/y5gahdtv (accessed 9 July 2019).

Hynd, C.R. (1999) 'Teaching students to think critically using multiple texts in history'. Journal of Adolescent and Adult Literacy, 42 (6), 428-36.

Jeismann, K.-E. (1992) 'Geschichtsbewusstsein'. In Bergmann, K., Kuhn, A., Rüsen, J. and Schneider, G. (eds) Handbuch der Geschichtsdidaktik. Seelze-Velber: Kallmeyer, 40-3.

Johansson, M. (2012) Historieundervisning och interkulturell kompetens. Karlstad: Karlstads universitet.

Johansson, P. (2019) 'Historical enquiry with archaeological artefacts in primary school'. Nordidactica: Journal of Humanities and Social Science Education, 1, 78-104.

Johansson, P. and Thorsten, A. (2017) 'Experiences from the teacher-researcher's perspective on learning study: Challenges and opportunities'. International Journal for Lesson and Learning Studies, 6 (1), 45-55.

Körber, A. and Meyer-Hamme, J. (2015) 'Historical thinking, competencies, and their measurement: Challenges and approaches'. In Ercikan, K. and Seixas, P. (eds) New Directions in Assessing Historical Thinking. New York: Routledge, 89-101.

Larsson, S. (2005) 'Om kvalitet i kvalitativa studier'. Nordisk Pedagogik, 25 (1), 16-35.

Larsson, S. (2009) 'A pluralist view of generalization in qualitative research'. International Journal of Research and Method in Education, 32 (1), 25-38.

Lee, P.J. (2005) 'Putting principles into practice: Understanding history'. In Donovan, M.S. and Bransford, J.D. (eds) How Students Learn: History, mathematics, and science in the classroom. Washington, DC: National Academies Press, 31-77.

Levstik, L.S. and Barton, K.C. (2015) Doing History: Investigating with children in elementary and middle schools. 5th ed. New York: Routledge.

Levstik, L.S. and Henderson, A.G. (2016) 'A human dependence on things: Fifth-graders' conceptions of human intelligence, innovation and agency'. In Éthier, M.-A. and Mottet, E. (eds) De nouvelles voies pour la recherche et la pratique en histoire, géographie et éducation à la citoyenneté. Brussels: De Boeck, 15-23.

Levstik, L.S., Henderson, A.G. and Lee, Y. (2014) 'The beauty of other lives: Material culture as evidence of human ingenuity and agency'. The Social Studies, 105 (4), 184-92.

Levstik, L.S. and Smith, D.B. (1996) " "I've never done this before": Building a community of historical inquiry in a third-grade classroom'. In Brophy, J. (ed.) Teaching and Learning History (Advances in Research on Teaching 6). Greenwich, CT: JAI Press, 85-114.

Levstik, L.S. and Thornton, S.J. (2018) 'Reconceptualizing history for early childhood through early adolescence'. In Metzger, S.A. and McArthur Harris, L. (eds) The Wiley International Handbook of History Teaching and Learning. Hoboken, NJ: Wiley-Blackwell, 473-502.

Linn, M.C., Davis, E.A. and Bell, P. (eds) (2004) Internet Environments for Science Education. Mahwah, NJ: Lawrence Erlbaum Associates.

Lo, M.L. (2012) Variation Theory and the Improvement of Teaching and Learning. Göteborg: Göteborgs universitet.

Lubar, S. and Kingery, D. (2013) History from Things: Essays on material culture. Rev. ed. Washington, DC: Smithsonian Books.

Marton, F. (2015) Necessary Conditions of Learning. New York: Routledge.

Marton, F. and Booth, S. (1997) Learning and Awareness. Mahwah, NJ: Lawrence Erlbaum Associates.

McGrew, S., Ortega, T., Breakstone, J. and Wineburg, S. (2017) 'The challenge that's bigger than fake news: Civic reasoning in a social media environment'. American Educator, 41 (3), 4-9.

Melander, H. and Sahlström, F. (2009) 'In tow of the blue whale: Learning as interactional changes in topical orientation'. Journal of Pragmatics, 41 (8), 1519-37.

Moore, H. (2018) 'Ordinary Roman life: Using authentic artefacts to achieve meaning'. Primary History: The Primary Education Journal of the Historical Association, 80, 12-13.

New Zealand Ministry of Education (2010) New Zealand Curriculum Guides: Senior secondary history (Version 2). Online. https://seniorsecondary.tki.org.nz/layout/set/pdf/content/view/ pdf/929 (accessed 13 July 2019). 
Nichol, J. (2005) 'Explaining past events through drama. Exemplar: The thing and Viking migration'. Nuffield Primary History Project. Online. www.history.org.uk/files/download/7131/1291382714/ vikingthingexemplar329.pdf (accessed 4 August 2019).

Nichol, J. (2010a) 'Editorial: "Doing history" with artefacts and objects'. Primary History: The Primary Education Journal of the Historical Association, 54, 4.

Nichol, J. (2010b) 'Editorial: History is literacy: Pupils "Doing history" with printed and written sources'. Primary History: The Primary Education Journal of the Historical Association, 56, 4.

Nichol, J. (2010c) 'Difficult and challenging reading: Genre, text and multi-modal sources - text breaker'. Primary History: The Primary Education Journal of the Historical Association, 56, 8-9.

Noboa, J. (2012) 'Missing pages from the human story: World history according to Texas standards'. Journal of Latinos and Education, 11 (1), 47-62.

Nokes, J.D. and Dole, J.A. (2004) 'Helping adolescent readers through explicit strategy instruction'. In Jetton, T.L. and Dole, J.A. (eds) Adolescent Literacy Research and Practice. New York: Guilford Press, 162-82

Nordgren, K. (2017) 'Powerful knowledge, intercultural learning and history education'. Journal of Curriculum Studies, 49 (5), 663-82.

Nordgren, K. and Johansson, M. (2015) 'Intercultural historical learning: A conceptual framework'. Journal of Curriculum Studies, 47 (1), 1-25.

Norrby, C. (2004) Samtalsanalys: Så gör vi när vi pratar med varandra. 2nd ed. Lund: Studentlitteratur.

Nuffield Primary History Project (2010) 'Sutton Hoo: Classroom archaeology in the digital age'. Primary History: The Primary Education Journal of the Historical Association, 54, 34-7.

Nygren, T. (2011) 'UNESCO and Council of Europe guidelines, and history education in Sweden, c. 1960-2002'. Education Inquiry, 2 (1), 37-60.

Nygren, T. and Guath, M. (2018) 'Mixed digital messages: The ability to determine news credibility among Swedish teenagers'. In Sampson, D.G., Ifenthaler, D. and Isaías, P. (eds) Proceedings of the 15th International Conference on Cognition and Exploratory Learning in Digital Age (CELDA 2018). International Association for Development of the Information Society, 375-8. Online. https://tinyurl.com/y2h7fums (accessed 13 July 2019).

Nygren, T., Haglund, J., Samuelsson, C.R., Af Geijerstam, Å. and Prytz, J. (2019) 'Critical thinking in national tests across four subjects in Swedish compulsory school'. Education Inquiry, 10 (1), 56-75.

Plomp, T. (2013) 'Educational design research: An introduction'. In Plomp, T. and Nieveen, N. (eds) Educational Design Research: Part A: An introduction. Enschede: SLO, 11-50.

Pye, E. (ed.) (2016) The Power of Touch: Handling objects in museum and heritage contexts. London: Routledge.

Rathje, S. (2007) 'Intercultural competence: The status and future of a controversial concept'. Language and Intercultural Communication, 7 (4), 254-66.

Reisman, A. (2012a) 'The "document-based lesson": Bringing disciplinary inquiry into high school history classrooms with adolescent struggling readers'. Journal of Curriculum Studies, 44 (2), 233-64.

Reisman, A. (2012b) 'Reading like a historian: A document-based history curriculum intervention in urban high schools'. Cognition and Instruction, 30 (1), 86-112.

Reisman, A. and McGrew, S. (2018) 'Reading in history education: Text, sources, and evidence'. In Metzger, S.A. and McArthur Harris, L. (eds) The Wiley International Handbook of History Teaching and Learning. Hoboken, NJ: Wiley-Blackwell, 529-50.

Rogoff, B. (2003) The Cultural Nature of Human Development. New York: Oxford University Press.

Rouet, J.-F., Britt, M.A., Mason, R.A. and Perfetti, C.A. (1996) 'Using multiple sources of evidence to reason about history'. Journal of Educational Psychology, 88 (3), 478-93.

Rüsen, J. (2004a) 'How to overcome ethnocentrism: Approaches to a culture of recognition by history in the twenty-first century'. History and Theory, 43 (4), 118-29.

Rüsen, J. (2004b) 'Historical consciousness: Narrative structure, moral function, and ontogenetic development'. In Seixas, P. (ed.) Theorizing Historical Consciousness. Toronto: University of Toronto Press, 63-85.

Rüsen, J. (2005) History: Narration, interpretation, orientation. New York: Berghahn Books.

Sahlström, F. (2008) 'Där och då, här och nu - några reflektioner över möjligheterna för samtalsanalytisk lärandeforskning att analysera lärande mellan situationer'. VAKKI:n julkaisut, 35, 10-30. Online. https://tinyurl.com/y53fz8eq (accessed 13 July 2019). 
Schreiber, W., Körber, A., Von Borries, B., Krammer, R., Leutner-Ramme, S., Mebus, S., Schöner, A. and Ziegler, B. (2006) Historisches Denken, Ein Kompetenz-Strukturmodell. Roßdorf: TZ-Verlag \& Print $\mathrm{GmbH}$.

Seixas, P. (2006) 'What is historical consciousness?'. In Sandwell, R.W. (ed.) To the Past: History education, public memory, and citizenship in Canada. Toronto: University of Toronto Press, 11-22.

Seixas, P. and Morton, T. (2013) The Big Six Historical Thinking Concepts. Toronto: Nelson Education.

Shemilt, D. (1983) 'The Devil's locomotive'. History and Theory, 22 (4), 1-18.

Stahl, S.A., Hynd, C.R., Britton, B.K., McNish, M.M. and Bosquet, D. (1996) 'What happens when students read multiple source documents in history?'. Reading Research Quarterly, 31 (4), 430-56.

Stodolsky, S.S. (1998) The Subject Matters: Classroom activity in math and social studies. Troy, NY: Educator's International Press.

Stoel, G.L., Van Drie, J.P. and Van Boxtel, C.A.M. (2015) 'Teaching towards historical expertise: Developing a pedagogy for fostering causal reasoning in history'. Journal of Curriculum Studies, 47 (1), 49-76.

Stolare, M. (2017) 'Did the Vikings really have helmets with horns? Sources and narrative content in Swedish upper primary school history teaching'. Education 3-13: International Journal of Primary, Elementary and Early Years Education, 45 (1), 36-50.

Svanberg, F. (2003) Decolonizing the Viking Age. Stockholm: Almqvist and Wiksell International.

UNESCO (United Nations Educational, Scientific and Cultural Organization) (2006) UNESCO Guidelines on Intercultural Education. Paris: United Nations Educational, Scientific and Cultural Organization Online. https://tinyurl.com/6bfgaun (accessed 13 July 2019).

Van den Akker, J. (1999) 'Principles and methods of development research'. In Van den Akker, J., Branch, R.M., Gustafson, K., Nieveen, N. and Plomp, T. (eds) Design Approaches and Tools in Education and Training. Dordrecht: Kluwer Academic Publishers, 1-14.

Van den Akker, J. (2013) 'Curricular development research as a specimen of educational design research'. In Plomp, T. and Nieveen, N. (eds) Educational Design Research: Part A: An introduction. Enschede: SLO, 53-70.

VanSledright, B.A. (2002) 'Fifth graders investigating history in the classroom: Results from a researcher-practitioner design experiment'. Elementary School Journal, 103 (2), 131-60.

VanSledright, B. (2012) 'Learning with texts in history: Protocols for reading and practical strategies'. In Jetton, T.L. and Shanahan, C. (eds) Adolescent Literacy in the Academic Disciplines: General principles and practical strategies. New York: Guilford Press, 199-226.

VanSledright, B.A. and Kelly, C. (1998) 'Reading American history: The influence of multiple sources on six fifth graders'. Elementary School Journal, 98 (3), 239-65.

Vella, Y. (2010a) 'Artefacts in history education'. Primary History: The Primary Education Journal of the Historical Association, 54, 5.

Vella, Y. (2010b) 'Extending primary children's thinking through the use of artefacts'. Primary History: The Primary Education Journal of the Historical Association, 54, 14-17.

Von Heyking, A. (2004) 'Historical thinking in the elementary years: A review of current research'. Canadian Social Studies, 39 (1).

Wineburg, S. (2007) 'Unnatural and essential: The nature of historical thinking'. Teaching History, $129,6-11$.

Wineburg, S. (2016) 'Why historical thinking is not about history'. History News, 71 (2), 13-16.

Wineburg, S., Martin, D. and Monte-Sano, C. (2011) Reading Like a Historian: Teaching literacy in middle and high school history classrooms. New York: Teachers College Press.

Wineburg, S. and Reisman, A. (2015) 'Disciplinary literacy in history: A toolkit for digital citizenship'. Journal of Adolescent and Adult Literacy, 58 (8), 636-9. 